\title{
Dental Treatment Plan
}

National Cancer Institute

\section{Source}

National Cancer Institute. Dental Treatment Plan. NCI Thesaurus. Code C60747.

An outline of the clinical steps in the care of a dental patient that may include specific

services to be delivered, the frequency of services, expected duration/timing, and costs. 